International Journal of Scholarly Papers for Media and Communications

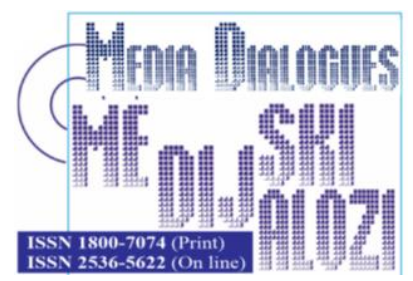

Brautovic, M. (2021), „E-Learning and Lifelong Education of Journalists: Case Study, Poynter Institute", Media Dialogues / Medijski dijalozi, Vol. 14, No. 3, pp. 31-41.

\title{
E-Learning and Lifelong Education of Journalists: Case Study, Poynter Institute
}

\author{
Associate Professor MATO BRAUTOVIC \\ University of Dubrovnik, Department of Communication, \\ Dubrovnik, Croatia
}

\begin{tabular}{|c|c|}
\hline $\boldsymbol{A} \boldsymbol{R} \boldsymbol{T} \boldsymbol{I C L} \boldsymbol{E}$ & Received: May 14, 2020 / Revised from: June 13, 2020 \\
$\boldsymbol{I} \boldsymbol{N} \boldsymbol{F} \boldsymbol{O}$ & Accepted: July 13, 2020 / Available online: January 15, 2021 \\
\hline $\boldsymbol{D O I}$ & doi.org/10.14254/1800-7074/14-1/4 \\
\hline
\end{tabular}

\begin{abstract}
This case study describes the lifelong education of journalists at one of the best institutions for journalism education, The Poynter Institute and its News University. News University was one of the first organizations to provide this form of education and now offers more than 85 courses. All courses are an extremely narrowly focused and available 24 hours a day, seven days a week. The problem of lack of adequate instructors is resolved through a partnership with 45 different institutions that are interested in the education of journalists. News University conducts four types of fully online courses: self-directed courses, online group seminars, webinars and seminar snapshots. Instructors at The Poynter Institute mentioned these issues as problems they encounter in leading the above-mentioned courses: technology problem, the problem of development of the course and limitations of online envi-
\end{abstract}


ronments to perform translational learning. The Future of News University is dependent upon of students and expansion of topics.

KEYWORDS: E-learning, lifelong education, journalism, communications, The Poynter Institute, News University.

\section{INTRODUCTION}

Lifelong education in any profession is the logical (and only possible) direction after education at higher education institutions. It is almost impossible to imagine any professionals who are not updating their knowledge after formal education.

In a time of economic crisis there is an increasing need for such education, whether to start a new career or acquire additional qualifications.. That need is equally present in the field of journalism. Newspapers and journalists who concentrated solely on print constantly recorded dropping circulation. Therefore, reporters are now forced to study the more modern forms of broadcast journalism and online journalism as a logical way to update their skills or take an alternative direction in their careers. With new technologies, the journalists have faced all kinds of major ethical problems that they are unable to respond because they do not have adequate knowledge. On the other hand, cost cutting in newsrooms has made editors less concerned about the education of young journalists.

According to a survey conducted by The Poynter Institute in 2004, 72 percent of journalists want to have eLearning training in the field of journalism to improve performance in their current jobs and advance their careers. On the other hand, factors such as course length, location, faculty, or even recommendations from supervisors - were not seen as "very important" by more than one-third of respondents (Poynter, 2004, 4).

However, because such studies are not conducted in Croatia, we can only make an educated guess about what is happening there. After the end ofthe war (19911995 ) in South East Europe and the political changes in year 2000 that led to the democratization of Croatian society, a large number of international activities educating journalists in Croatia ended. The Croatian Journalists Association and their International Center for Education of Journalists stopped running their journalism seminars.

There are five Croatian university programs in the field of journalism; none provide lifelong education. The only school of online journalism, run by the Institute for New Media, offered by the Faculty of Political Sciences (at the University of Zagreb) does not offer the ability to educate journalists, regardless of geographic location and in accordance with the needs of the workplace. 
The aim of this case study was to answer questions arising from the previously mentioned problems. The Poynter Institute has been chosen as the subject of the study because it is a leading institution in eLearning and in lifelong education of journalists in the world.

\section{METHODOLOGY}

The study was conducted as part of broader studies on models of journalism education as a part of the author's post doctoral training and was financed by a Fulbright exchange program.

The Poynter Institute and its Center for eLearning, News University - NewsU (www.newsu.org) were selected for analysis. In-depth interviews and document analysis were the methods used to collect data for the case study.

In-depth interviews were conducted with Howard Finberg, director of interactive learning at The Poynter Institute for Media Studies who is responsible for News University; Al Tompkins, a Poynter Institute faculty member; Vicki Krueger, the manager at News University; Casey Frechette and Vanessa Goodrum, interactive learning producers; and Sara Quinn and Regina McCombs, the lecturers at News Uni- versity and faculty at the Poynter Institute. Interviews were unstructured and conducted on October 19 and November 17, 2009 at The Poynter Institute.

Documents for analysis were selected based on criteria that explain the establishment of center, course list selection and the course content, audience and other relevant data.

\section{SHORT HISTORY AND ESTABLISHMENT OF NEWS UNIVERSITY}

Nelson Poynter (1903-1978), who was publisher of the St. Petersburg Times, founded the Poynter Institute as a school for education of journalists in excellence, editorial integrity and independent ownership. The Institute was founded in 1975 and financed with controlling stock of the Times Publishing Company and other donations.

There are two factors which led to the creation of News University. Howard Finberg started to work at The Poynter Institute as a Presidential Scholar. His research interest was to explore the intersection of technology, journalism and education. As result of his research, he wrote a report stating that Poynter should be involved in eLearning, but should not replicate the existing courses that are physically held in the Poynter Institute. According to his analysis, eLearning should solve several problems for the journalists:

- Courses must be very targeted and focused on specific knowledge that the journa- list wants to learn, restore or improve 
- Courses must respect participants' time. Journalists are very busy and don't have time to spend a full week on a course. It is more likely that they can spend several hours. This meant courses must be available 24 hours a day, seven days a week and must be self guided.

The second factor which led to the establishment of News University is that in 2002 The Knight Foundation sought a partner for an eLearning program. After The Poynter Institute expressed interest, The Knight Foundation gave the institute a grant for the first five years of News University's operation. After obtaining the grant, it took the Poynter personnel 18 months to launch the site, because they did not want to start with only one course. They needed a number of courses that would cover different areas of journalism.

When Poynter's News University launched 2005, the site had two goals (NewsU, 2009, 8):

- To serve as an eLearning portal that would take the best of training from across the journalism community and make it accessible using the Internet.

- To learn more about eLearning and share that information across the industry.

In April 2005, News University had 2247 students, while by February 2009 their number increased to more than 100,000 .

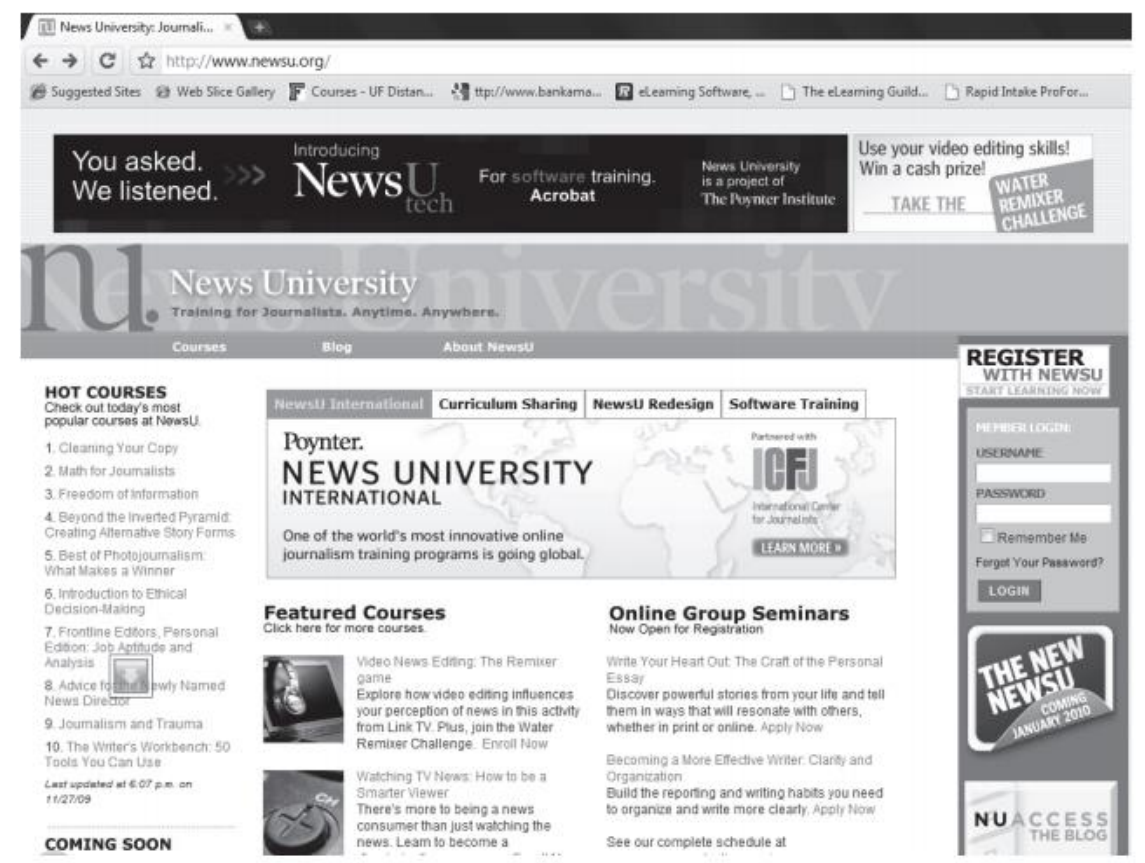

Figure 1. Home page of News University 


\section{ORGANIZATION OF NEWS UNIVERSITY}

News University is organized as a separate branch of The Poynter Institute. At the lead is a director whose job is to find partners Under the director's leadership are a manager and interactive learning producers and other staff. The role of the manager is the promotion and management. On the other side, the role of the interactive learning producer is the implementation of online interactive learning courses. The Interactive learning producer's job duties include project management, programming and development. News University, besides director and manager, employs two interactive learning producers, two assistant producers, one interactive design fellow and one interactive learning administrative assistant.

\section{TYPES OF COURSES AT NEWS UNIVERISTY}

In keeping with News University's initial goals, all courses are focused and they last for a period of few hours. Exceptions are online group seminars. News University offers 4 types of eLearning courses:

- Self-directed courses

- Online group seminars

- Webinars

- Seminar Snapshots

All four types of courses belong to the category of fully online eLearning - eLearning which is performed entirely in the online synchronous and asynchronous form with and without the participation of instructor.

Self-directed courses are online courses that are self guided, so students do not have contact with the instructor and classmates. A student starts and stops whenever he or she likes, progresses entirely at his or her pace and comes back any time to review material. These courses use learning activities, such as interactive games, simulations and multimedia, that are more engaging than a screen filled with text.

Online group seminars are structured much like a classroom course. Participants gather in virtual space - logging in from anywhere, day or night - over the course of several days or several weeks. An instructor guides the group through new materials, moderates discussions and provides individual feedback.

Webinars are synchronous courses. These are live seminars or events broadcast over the Internet. Students tune in from a home or office computer and ask questions of the instructor in real time. After the seminar ends, students can access recordings of the course.

The last category of course is a seminar snapshot. This type of course includes edited highlights from presentations, seminars and lectures at the Poynter Institute. 
At the beginning The Poynter Institute wanted to have only self-guided seminars, but they found that "rather than force the course to the container change the container" (Finberg, 2009) was in keeping with their initial goals. "We don't have a formula. We can't say put it in this container and it's done. The Problem how to transfer knowledge to eLearning environment we are solving collaboratively." (Finberg, 2009)

In addition to these courses, the University conducts News and Technology Training and Tutorials. The first consists of software simulations that give students a feel for working in programs like Flash, Dreamweaver and Illustrator without buying any software. Tutorials include step-by-step instructions and screen shots, which guide users and demonstrate the basics of working with these applications.

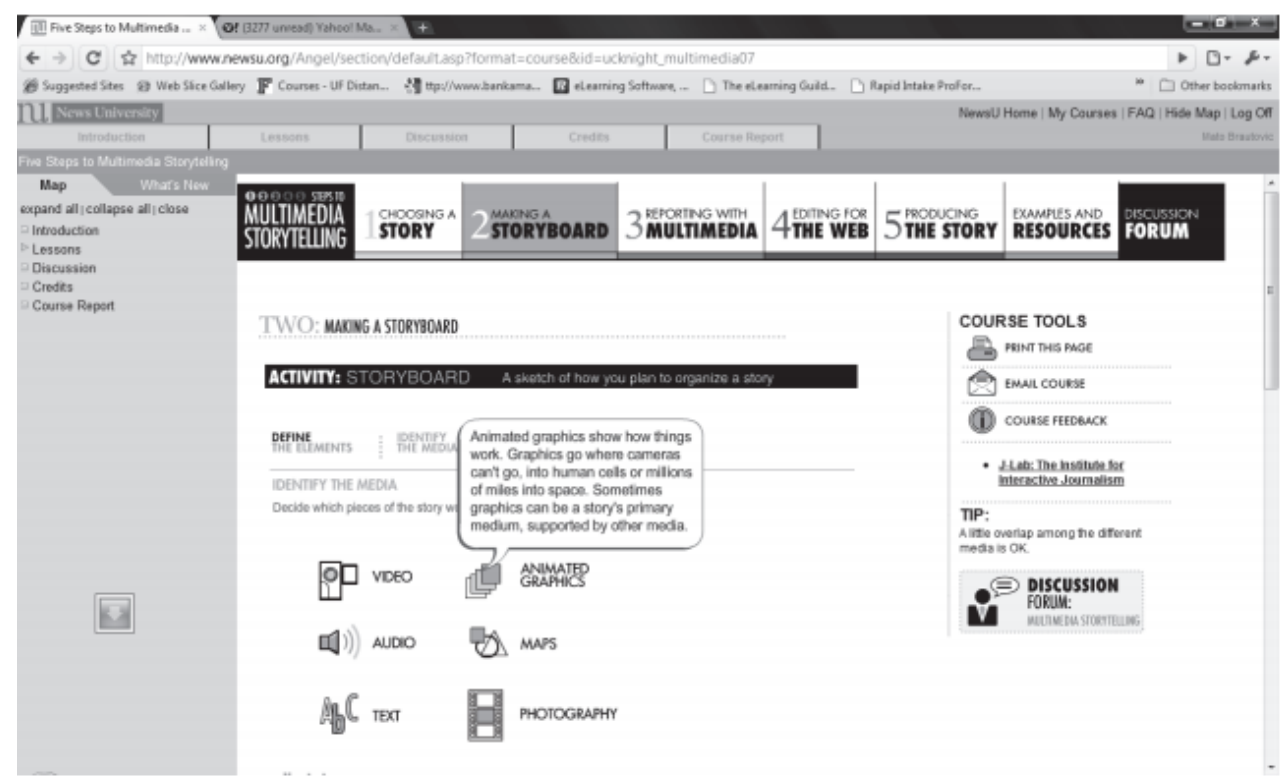

Figure 2. Print screen of course 5 steps to Multimedia Storytelling

\section{SELECTION OF COURSE TOPICS}

The education of journalists is facing several problems:

- The speed of changes and the introduction of new technological innovations

- Finding new instructors who have knowledge (actual and practical)

- Selection of the current trend (topics) which will be developed into courses 
Journalism today is really experimental because most newsrooms are mainly trying to find the best way to present content (multiplatform publishing) and business models that will lead to profit for publishers. Because of this, finding instructors with sufficient knowledge and selecting topics that will remain current after a few years is very hard, even impossible. The Poynter Institute found a solution for these problem - they went into partnership with a wide variety of course partners.

At the time this research was conducted, Poynter was a partner with 45 different institutions. News University offers expertise in eLearning and partner organizations offer knowledge and instructors.

Table 1. Partner institutions of The Poynter Institute

\begin{tabular}{|c|c|}
\hline Partner institution & Courses \\
\hline $\begin{array}{l}\text { American Association for Public } \\
\text { Opinion Research }\end{array}$ & Understanding and Interpreting Polls \\
\hline Annie E. Casey Foundation & $\begin{array}{l}\text { Covering Foster Care: A Seminar } \\
\text { Snap-shot }\end{array}$ \\
\hline $\begin{array}{c}\text { American Society of Newspaper } \\
\text { Editors }\end{array}$ & $\begin{array}{l}\text { Community Service Photojournalism: } \\
\text { Lessons from a Contest; Boot Camp } \\
\text { for Scholastic Journalism Advisers; } \\
\text { Introduction to Ethical Decision- } \\
\text { Making }\end{array}$ \\
\hline Dart Center for Journalism \& Trauma & Journalism and Trauma \\
\hline $\begin{array}{c}\text { Department of Journalism, J-Ideas, } \\
\text { Ball State University } \\
\end{array}$ & $\begin{array}{c}\text { First Amendment Training for the } \\
\text { High School Journalist }\end{array}$ \\
\hline Frontline Editors Project & $\begin{array}{l}\text { Frontline Editors Introduction: Under- } \\
\text { standing Leadership Styles; Frontline } \\
\text { Editors, Personal Edition: Job Aptitude } \\
\text { and Analysis }\end{array}$ \\
\hline GuideStar & Reporting on Nonprofits \\
\hline $\begin{array}{l}\text { Hechinger Institute on Education and } \\
\text { the Media }\end{array}$ & On the Beat: Covering Education \\
\hline $\begin{array}{c}\text { International Reporting Project, Johns } \\
\text { Hopkins University School of } \\
\text { Advanced International Studies }\end{array}$ & $\begin{array}{l}\text { International Reporting Basics: What } \\
\text { You Need to Know Before You Go }\end{array}$ \\
\hline Kent State University & $\begin{array}{l}\text { Boot Camp for Scholastic Journalism } \\
\text { Advisers }\end{array}$ \\
\hline $\begin{array}{c}\text { Knight Center for Specialized } \\
\text { Journalism, Merrill College of } \\
\text { Journalism, University of Maryland }\end{array}$ & $\begin{array}{c}\text { The Economy in Turmoil: Challenges } \\
\text { to the White House, the Statehouse and } \\
\text { Your House }\end{array}$ \\
\hline Knight Digital Media Center, & $\begin{array}{l}\text { Five Steps to Multimedia Storytelling; } \\
\text { Using Social Media to Build Audience }\end{array}$ \\
\hline
\end{tabular}




\begin{tabular}{|c|c|}
\hline $\begin{array}{l}\text { University of California-Berkeley } \\
\text { Graduate School of Journalism }\end{array}$ & \\
\hline The Maynard Institute & $\begin{array}{l}\text { Anatomy of a Multimedia News Orga- } \\
\text { nization; Anatomy of a Newspaper: } \\
\text { Understanding the Business }\end{array}$ \\
\hline Media Bloggers Association & $\begin{array}{l}\text { Online Media Law: The Basics for } \\
\text { Bloggers and Other Online Publishers }\end{array}$ \\
\hline $\begin{array}{l}\text { Metcalf Institute for Marine and } \\
\text { Environmental Reporting }\end{array}$ & $\begin{array}{l}\text { Covering Climate Change: A Seminar } \\
\text { Snapshot }\end{array}$ \\
\hline $\begin{array}{c}\text { National Association of Black } \\
\text { Journalists }\end{array}$ & $\begin{array}{l}\text { NABJ Webinar Series, Part I: Making } \\
\text { the Transition to Supervisor; NABJ } \\
\text { We- binar Series, Part II: Coaching } \\
\text { and Counseling for Outstanding } \\
\text { Perfor- mance; NABJ Webinar Series, } \\
\text { Part III: Managing Today's } \\
\text { Newsroom: Doing More with Less; } \\
\text { NABJ Webinar Series, Part IV: } \\
\text { Mastering Newsroom Politics: Making } \\
\text { Alliances and Wielding Influence }\end{array}$ \\
\hline $\begin{array}{c}\text { National Press Photographers } \\
\text { Association }\end{array}$ & $\begin{array}{l}\text { Best of Journalism: What Makes a } \\
\text { Winner; Lessons from a Contest: } \\
\text { Inside NPPA 2008: Broadcast; } \\
\text { Lessons from a Contest: Inside NPPA } \\
\text { 2008: Still Photography and Web } \\
\text { Sites. }\end{array}$ \\
\hline $\begin{array}{c}\text { National Sexual Violence Resource } \\
\text { Center }\end{array}$ & Covering Sexual Assault \\
\hline Newseum, Knight Foundation & $\begin{array}{c}\text { The "Be a Reporter" Game: the "Be an } \\
\text { Editor" Game }\end{array}$ \\
\hline $\begin{array}{c}\text { Newspaper Association of America } \\
\text { Foundation }\end{array}$ & $\begin{array}{c}\text { Coaching Tomorrow's Journalists; } \\
\text { Targeting New Audiences: Finding } \\
\text { Your Niche }\end{array}$ \\
\hline Online News Association & Developing online journalism projects \\
\hline $\begin{array}{c}\text { Radio and Television News Directors } \\
\text { Foundation }\end{array}$ & $\begin{array}{c}\text { Advice for the Newly Named News } \\
\text { Director; Introduction to Ethical } \\
\text { Decisi- on-Making; Reporting Across } \\
\text { Platforms }\end{array}$ \\
\hline $\begin{array}{l}\text { Reynolds Journalism Institute at } \\
\text { Missouri School of Journalism }\end{array}$ & $\begin{array}{l}\text { Local Readers and the Newsroom: The } \\
\text { Online Credibility Gap }\end{array}$ \\
\hline Reznet & Faculty-led advanced reporting course \\
\hline
\end{tabular}




\begin{tabular}{|c|c|}
\hline Society of Environmental Journalists & $\begin{array}{l}\text { Covering Climate Change: A Seminar } \\
\text { Snapshot; Covering Water Quality: } \\
\text { What You Need to Know }\end{array}$ \\
\hline $\begin{array}{c}\text { Suburban Newspapers of America } \\
\text { Foundation }\end{array}$ & $\begin{array}{l}\text { Build and Enlarge Local Audiences } \\
\text { Online; Leading an Online Newsroom: } \\
\text { What You Need to Know }\end{array}$ \\
\hline Society of Professional Journalists & $\begin{array}{l}\text { Freedom of Information; Introduction } \\
\text { to Ethical Decision-Making }\end{array}$ \\
\hline Stony Brook University & $\begin{array}{l}\text { Watching TV News: How to Be a } \\
\text { Smarter Viewer }\end{array}$ \\
\hline $\begin{array}{c}\text { Western Kentucky University School } \\
\text { of Journalism and Broadcasting }\end{array}$ & $\begin{array}{c}\text { Best of Photojournalism: What Makes } \\
\text { a Winner }\end{array}$ \\
\hline
\end{tabular}

As an example of this cooperation, Finberg points to the Climate Change course which was just implemented with help of the University of Colorado. The University of Colorado has an expert on climate change, and there is no need for a Poynter faculty member in the field of climate change. Therefore, Poynter contacted the University of Colorado, which identified the instructor who is the subject matter expert, and with his help they have developed content for a Poynter course (Finberg, 2009).

Interactive learning producer Casey Frechette stressed that the subject matter expert is not expected to have teaching experience. "Of course it's good that our subject matter experts have teaching experience, but the News University is there to help create content for the course. My job of Interactive learning producer is to take their content knowledge and to translate it into something that is not only good teaching but good eLearning." (Frechette, 2009)

Courses cover the areas of advertising, broadcast, design, diversity, editing, ethics, journalism basics, management, media audiences, convergence, newspapers, print, online, multimedia, photo journalism, reporting, writing and software.

\section{USERS OF COURSES}

News University is oriented toward journalism beginners and those with experience up to ten years (Krueger, 2009). Since April 2005, News University's courses have been taken by more than 100,000 users. According to registration data, 35 percent of users are journalists and editors, 20 percent are journalism students, and 5 percent are educators in the field of journalism. Fifty percent of participants are newspaper reporters, 25 percent are online journalists and 25 percent are TV and radio journalists. (NewsU, 3 ) 
The 10 countries with the most registered users are the United States, Canada, India, Australia, Philippines, the United Kingdom, China, Brazil, South Africa and Nigeria (NewsU, 4).

An interesting phenomenon is that a large number of educators in the field of journalism encourage their students to take News University courses. Also, a large number of educators (as seen from previous data), use the courses.

"We know a number of teachers who are using News University for supplementing their work. They are telling us that News University has more power then textbooks. Students like interactivity and examples from real life, which are more updated than in textbooks. We become an adjunct member of many journalism departments.'(Finberg, 2009)

\section{PROBLEMS IN IMPLEMENTATION OF COURSES}

The Poynter Institute emphasizes the importance of a high level of student satisfaction. However, they warn that a major problem can be caused by technology. Sara Quinn, an instructor with years of experience in eLearning and the education of journalists discusses the problem of technology.

"What if at the time of performing a webinar online group seminar, or for technical reasons, 20 to 50 registered students cannot access the course? Then they will ask for notes or later you will be called and written e-mails and you have to do all the work over again". (Quin, 2009)

Director Finberg, on the other hand, draws attention to the problem of eLearning as a teaching method.

"There are problems of completion, assessment, development problems, because eLearning courses are not easy to develop. It takes longer than most people realize...It's still just an eLearning. In a classroom you can ask 'Do you understand me?' ELearning is impersonal. We are looking at ways to improve personalization of eLearning and making that a more satisfying experience for students. ELearning is not an answer to all the problems in teaching." (Finberg, 2009)

Al Topkins warns of the lack of nonverbal communication, which makes ELearning very difficult to use for transformational learning.

"ELearning is the best for skills learning. To teach somebody how to edit. To teach somebody fundamentals of photography. To teach somebody how to write. All of these things are skills and eLearning is very good for that. ELearning is less useful for transformational learning, where I have to build a trust before I discover personal information and problems. Where trust is the issue, eLearning is not a solution. ELearning is a very good method for one-to-many teaching." (Topkins, 2009) 


\section{THE FUTURE OF NEWS UNIVERSITY}

Finberg said that in the future they will expand the number of courses and they will start with the internationalization of courses. "The intention is to develop more courses in several languages, but to do this we must find funding. It's not enough to translate courses into another language; they must be localized. Courses must be relevant for journalists in that language group, which will allow courses to be effective." (Finberg, 2009)

\section{CONCLUSION}

As we see from the case study, eLearning is a solution to the need for lifelong education of journalists. The approach that was chosen at The Poynter Institute shows us that journalists should be aware of the knowledge that they can get without geographical and time constraints ( 24 hours, seven days a week).

However, eLearning also has problems. It is good for learning skills, but not for transformational learning. There is also a problem with technology.

The Poynter Institute and News University are successful examples of how technology can be used to improve any profession, in this case journalism.

\section{LITERATURE \& SOURCES}

Finberg, H. (2009), Interview on 17. November 2009. [Recording in possession of a- uthor].

Frechette, C. (2009), Interview on 17. November 2009. [Recording in possession of author].

Goodrum, V. (2009), Interview on 17. November 2009. [Recording in possession of author].

Krueger, V. (2009), Interview on 15. October 2009. [Recording in possession of author].

McCombs, R. (2009), Interview on 15. October and 17. November 2009. [Recording in possession of author].

NEWSU (2009), NewsU Serves Global E-Learning Audience. [Brochure],

Tompkins, Al., Interview on 17. November 2009. [Recording in possession of author] 